\section{Effects of Depth and Duration of Burial on Tanglehead (Heteropogon contortus) Seed Viability and Germination in Southern Texas $\curvearrowright$}

Joshua L. Grass (Caesar Kleberg Wildlife Research Institute, Texas A\&M University-Kingsville, Kingsville, TX, 78363), Aaron D. Tjelmeland (The Nature Conservancy, Texas City Prairie Preserve, Texas City, TX, 77590), Forrest S. Smith, (Caesar Kleberg Wildlife Research Institute, Texas A\&M University-Kingsville, Kingsville, TX, 78363), Scott L. Mitchell (Caesar Kleberg Wildlife Research Institute, Texas A\&M University-Kingsville, Kingsville, TX, 78363), Sandra Rideout-Hanzak (Caesar Kleberg Wildlife Research Institute and Dept. of Animal, Rangeland and Wildlife Sciences, Texas A\&M University-Kingsville, Kingsville, TX, 78363-8202), John Lloyd-Reilley (E. "Kika" de la Garza Plant Materials Center, USDA NRCS, Kingsville, TX, 78363-2704), Shelly D. Maher (E. "Kika" de la Garza Plant Materials Center, USDA NRCS, Kingsville, TX, 783632704) and David B. Wester (corresponding author: Caesar Kleberg Wildlife Research Institute and Dept. of Animal, Rangeland and Wildlife Sciences, Texas A\&M UniversityKingsville, Kingsville, TX 78363, david.wester@tamuk.edu).

T anglehead (Heteropogon contortus) is a perennial $\mathrm{C}_{4}$ grass with a world-wide distribution in warm climates (Gould 1968, Everitt et al. 2011). Tanglehead is indigenous to the southwestern US on sandy and rocky soils (Gould 1978, Stubbendieck et al. 2003, Everitt et al. 2011); its occurrence in late-Wisconsin aged packrat middens in the Sonoran Desert confirms its presence over 12,000 years ago (Van Devender 1990). Carter (1958) considered tanglehead one of the primary grasses in south Texas prior to European settlement and subsequent shrub invasion.

Tanglehead is fair to good cattle forage (Everitt et al. 2011) especially when grazed early in the growing season (Powell 1994) or after fire (Everitt et al. 2011) but of little grazing value for sheep (Stubbendieck et al. 2003) and wildlife (Gould 1978). Tanglehead provides excellent nesting cover for northern bobwhite quail (Colinus virginianus) and wild turkey (Meleagris gallopavo intermedia) and fawning cover for white-tailed deer (Odocoileus virginianus) (Everitt et al. 2011).

Tanglehead populations have increased dramatically over the past 15 years in the south Texas Coastal Sand Sheet. Many ecologists consider tanglehead invasive in this area because of its ability to rapidly transform landscapes with high floral diversity into monotypic stands; a major consequence is reduced wildlife habitat quality (Bielfelt 2013).

D This open access article is distributed under the terms of the CC-BYNC-ND license (http://creativecommons.org/licenses/by-nc-nd/3.0) and is freely available online at: http://er.uwpress.org
A key to better understanding tanglehead populations is through its recruitment dynamics. Tothill (1970) confirmed Emery and Brown's (1958) report that Australian tanglehead was an obligate apomict, and Carino and Daehler (1999) provided evidence of frequent sexual reproduction of Hawaiian populations. Pathak and Parihar (2004) reported yields of 20,000 to 23,000 seeds $\mathrm{m}^{-2}$ and over 300 $\mathrm{kg} \mathrm{ha}^{-1}$ pure seed. Here we report results from two field trials that document the effects of year of seed production, seed burial depth, and seed burial duration on seed viability and germination at three study locations in south Texas, US. Management implications to reduce the impact of this invasive species are also discussed.

Two field trials were conducted between 2010 and 2015 . In Trial 1, tanglehead seeds were harvested by hand from plants on two private ranches in south Texas (Duval Co., Loamy Sand Ecological Site (Natural Resources Conservation Service site ID: R083EY705TX); and Hidalgo Co., Sandy Loam Ecological Site: R083EY702TX) in November 2010 and buried on these ranches in December 2010. In Trial 2, seeds were harvested from plants at an additional study site (Duval Co., Loamy Sand Ecological Site: R083EY705TX) in November 2012; seeds from 2010 and 2012 Duval Co. collections were buried in February 2013 at 5 locations (separated by at least $500 \mathrm{~m}$ ) at a study site (Sandy Loam Ecological Site: R083CY463TX) in Brooks Co., TX. Collected seeds were stored in paper envelopes at room temperature $\left(23^{\circ} \mathrm{C}\right)$ until burial (Tothill 1977). Seeds were placed in aluminum mesh bags $(0.011 \mathrm{~mm}$ mesh; 50 seeds per bag) and buried at $3.8 \mathrm{~cm}$ or $8.9 \mathrm{~cm}$. In Trial 1 , bags were buried at $1-\mathrm{m}$ intervals along $20-\mathrm{m}$ transects, and in Trial 2, bags were buried at 1-m intervals along 5-m transects. In Trial 1, 20 bags from each burial depth at each location were recovered in June 2011 (6-month burial) and in January 2012 (12-month burial). In Trial 2, 5 bags were recovered on 7 dates beginning 3 months after burial and ending 25 months after burial. Following retrieval, some bags contained seeds that had germinated during burial; all non-germinated seeds from each pouch were counted, pre-chilled at $7^{\circ} \mathrm{C}$ for 10 to 14 days, and placed in petri dishes in a germination chamber $(12 \mathrm{~h}$ dark at $27^{\circ} \mathrm{C}$ and $12 \mathrm{~h}$ light at $35^{\circ} \mathrm{C}$; see Wester 1991); the number of germinated seeds was recorded after 14 days. Pre-burial tetrazolium viability tests (AB Seed Laboratory, Norcross, GA) indicated $91 \%$ viability for Trial 1; for Trial 2, initial viability was $100 \%$ and $97.9 \%$ for 2010 - and 2012-collected seeds, respectively. In Trial 1, post-recovery viability tests were not conducted; in Trial 2, post-recovery tetrazolium viability tests were conducted on seeds that did not germinate following each retrieval.

Percent germination was analyzed with a generalized linear model and a logit link function (SAS v 9.3, SAS Institute, Cary, NC). In Trial 1, fixed effects included depth, duration of burial and their interaction; random effects were study site location (a block effect), the interaction 


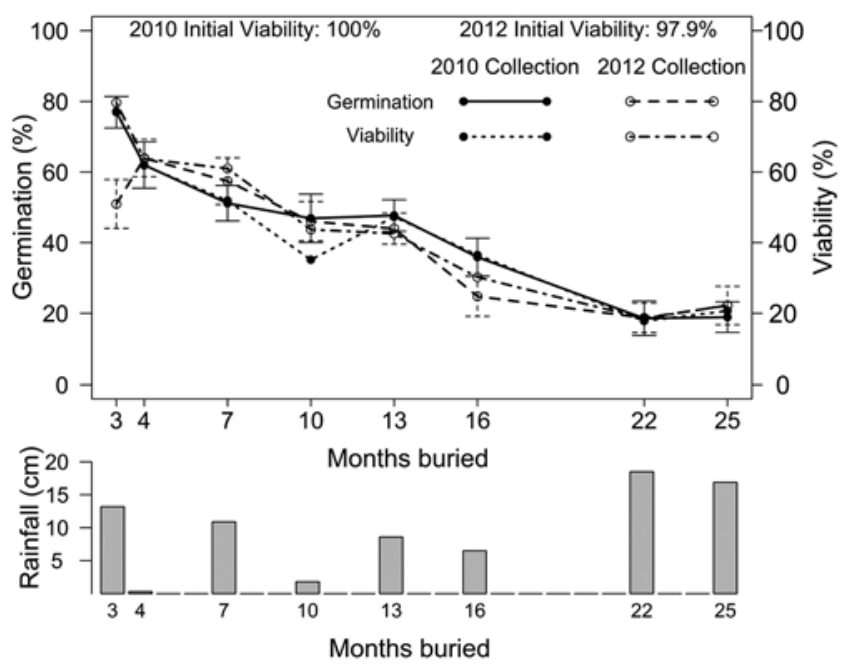

Figure 1. Trial 2 results: seed germination (\%) ( \pm SE) of tanglehead seeds (collected in 2010 or 2012) under growth chamber conditions $\left(12 \mathrm{~h}\right.$ dark at $27^{\circ} \mathrm{C}$ and $12 \mathrm{~h}$ light at $35^{\circ} \mathrm{C}$ ) after burial at 3.8 or $8.9 \mathrm{~cm}$ depths for $\mathbf{3}$ to $\mathbf{2 5}$ months following burial (solid and dashed lines). Results are averaged over depths of burial. Initial viability as well as post-burial viability (2010: dotted line; 2012: dashed and dotted line) (\%) ( \pm SE) are also shown. Rainfall is cumulative rainfall $(\mathrm{cm})$ between retrieval dates.

between location, depth and burial (experimental error), and bag nested in location, depth and duration of burial (a sampling error; Steel et al. 1997). In Trial 2, fixed effects included year of collection, depth of burial, and duration of burial; random effects included location and the interaction between location and depth (the error term for the depth test). For both trials, several covariance structures were modelled to account for location effects (first-order auto-regressive and Toeplitz structures and heteroscedastic versions of these structures); the model with a generalized chi-square statistic closest to the value of 1 was chosen as the best structure (Meyers et al. 2002).

Rainfall December 2010 through January 2012 totaled 23.88 and $28.07 \mathrm{~cm}$ at Duval and Hidalgo Co. study sites, respectively. In Trial 1 , seed germination decreased $\left(\mathrm{F}_{1,3}\right.$ $=92.99, p=0.0024)$ from $50 \%( \pm 12.43 \%)$ after 6 months burial time to $1.7 \%( \pm 1.1 \%)$ at 12 months burial time. The effect of burial depth was weak $\left(\mathrm{F}_{1,3}=9.29, p=0.0555\right)$, with $19.9 \%( \pm 8.2 \%)$ germination at $3.8 \mathrm{~cm}$ and $6.4 \%$ $( \pm 3.8 \%)$ germination at $9.8 \mathrm{~cm}$. Burial depth and duration acted independently $\left(\mathrm{F}_{1,3}=4.59, p=0.1216\right)$ in their effects on germination.

Rainfall at the Brooks Co. study site from February 2013 through March 2014 and April 2014 through March 2015 totaled 33.10 and $43.61 \mathrm{~cm}$, respectively. In Trial 2, germination declined $\left(\mathrm{F}_{7,51.6}=20.26, p<0.0001\right)$ as burial time lengthened, an effect that was independent $\left(\mathrm{F}_{7,53.2}=\right.$ $4.10, p=0.2267$ ) of the combination of burial depth and year of collection (Figure 1$)$. There was a weak $\left(\mathrm{F}_{7,52.8}\right.$
$=1.94, p=0.0820)$ interaction between burial time and year of collection: there were no differences $(p>0.1359)$ between years of collection on all retrieval dates except at 3 months $\left(F_{1,54.92}=26.41, p<0.0012\right)$. Post-burial viability likewise declined $\left(\mathrm{F}_{7,15.91}=20.26, p<0.0001\right)$ with length of burial; no other effects or interactions were significant ( $p>0.3758)$.

Of all the stages in a plant's life cycle, mortality is highest for seeds (Leck et al. 2008). Soil seed numbers decline because of release from dormancy and loss of viability through ageing (El-Maarout-Bouteau et al. 2011), mortality (Brown et al. 1979), and disease (Leishman et al. 2000); prolonged exposure to these factors increases mortality (Roberts 1962). The reduced tanglehead germination we documented was likely manifested through these effects experienced during burial.

Baldos et al. (2014) reported low germination (10\%) of freshly-harvested tanglehead seeds, indicating that dormancy loss can be hastened by increasing storage temperatures from $20^{\circ} \mathrm{C}$ to $30^{\circ} \mathrm{C}$. Our seeds were stored at room temperature for 30 days (Trial 1) and up to 24 months (Trial 2) prior to burial, and germination upon retrieval was relatively high (50\% after 6 months in Trial 1 and 50-80\% after 3 months in Trial 2), suggesting that our seeds had little dormancy.

We did not detect effects of burial depth on subsequent tanglehead germination in either field trial. Depth effects on seed germination, however, are species-specific (e.g., Boyd and Van Acker 2003), and relationships between seed characteristics (e.g., size or weight) and ability to emerge at depth are complex (Grundy et al. 2003). We detected only a weak interaction between year of collection and duration of burial. Tothill (1977) reported high germination of tanglehead seeds stored at room temperature for up to 39 months; our results support this. Two-year old seeds that were buried generally had similar germination responses throughout our 25-mo burial trial as freshly harvested seeds that were buried. The similarity in overall results between Trials 1 and 2 (conducted at different field sites and in different years) suggests that our duration-of-burial responses as well as the absence of a strong depth-of-burial effect are robust findings.

Seed burial can enforce dormancy on seeds of some species that are shed in a nondormant condition (Zhu et al. 2009). Tothill (1977) could not determine that light was required for tanglehead germination, and we have excavated numerous seedlings in the field with seeds, located at ca. $3 \mathrm{~cm}$ below the soil surface, still attached to the base of the subcoleoptilar internode; thus, it is unlikely that light is required for tanglehead germination. A complete understanding of the many factors that affect dormancy (e.g., Wester 1995) is beyond the scope of this study. Tothill (1977) identified two tanglehead dormancy mechanisms: (1) endogenous dormancy that can be relieved by gibberellic acid, and (2) exogenous inhibition associated with seed 
appendages. Tothill (1977) showed that appendage (glumes, lemma) removal relieved seed dormancy under laboratory conditions; these appendages, however, were essential to maintenance of seed viability in the field. We planted perfect spikelets with glumes and lemma intact. Viability tests immediately following retrieval from the field in Trial 2 indicate that the decline in germination we observed was due to loss of viability rather than enforced dormancy.

Seedbank management methods have been developed in agronomic settings where impacts of weeds have strong economic implications and management practices can be controlled in a coordinated cropping system. Applying these strategies in natural vegetation settings, however, is challenging. In practice, options include methods that affect (1) seed input into a soil seedbank and (2) persistence of seeds in the soil bank.

Limiting seed input is the most obvious method to reduce the size of a soil seedbank (Gulden and Shirtliffe 2009): practices should be targeted to prevent flowering of unwanted plants or destroy seeds on the mother plant before they are dispersed. In native vegetation, prescribed burning can be effective for tanglehead: prescribed fire in the spring can kill up to $60 \%$ of adult tanglehead plants (Grace et al. 2015), and fire in summer or autumn destroys seeds on mature plants prior to dispersal. However, tanglehead seedling emergence following fire is prodigious: we have documented 1,500 seedlings $\mathrm{m}^{-2}$ following spring burning; additionally, tanglehead seedling emergence occurs up to 3 months sooner in burned pastures than in nonburned pastures (Grace et al. 2015). A more effective strategy to limit seed input into soil seedbanks may be to use fire in combination with herbicides. For example, summer prescribed fire and Arsensal ${ }^{\circledR}-$ Powerline $^{\mathrm{Tm}}$ can reduce tanglehead plant density for up to 2 years following treatment (Grace et al. 2015).

Tillage can impact seed persistence in soils by affecting both seedbank size and distribution of seeds in the soil. Discing is a common practice in south Texas rangelands dominated by tanglehead where its typical immediate goal is to stimulate forb production for wildlife. Whereas discing may also kill adult tanglehead plants, it generally affects only the top $15-20 \mathrm{~cm}$ of soil; as such, shallow discing is a relatively conservative tillage practice. There is evidence that such practices can reduce seedbank size in comparison to, for example, moldboard plowing; however, a larger percentage of seeds are nearer the surface in conservative tillage (Clements et al. 1996). Therefore, although discing can bury seeds, it is also likely that (formerly) buried seeds are brought to the surface as well, and this would increase tanglehead populations in the long run (Clements et al. 1996). Given that discing also kills desirable native plants and tanglehead buries its own seeds (Peart 1979), it is unlikely that discing, as a seed burial method, can be justified, particularly in plant communities that include a mixture of both tanglehead and native species.
Although dormancy is not required for the formation or persistence of seed banks (Honda 2008), reduced germination because of secondary dormancy enforced by burial can provide a means for a species to form a persistent seed bank. Our results suggest, however, that because of loss of viability that we observed during burial, the formation of persistent tanglehead seed banks is unlikely. Management strategies that limit seed input into the soil seedbank and that maintain effective seed burial for at least 25 months may be useful tools in restoration of tanglehead-dominated rangelands.

\section{Acknowledgments}

We would like to thank the Wagner Ranch, the Anacahuita Ranch, and the East Foundation for allowing us to conduct this research on their properties, and managers Mr. Irvin Welch, Mr. Casey Pritchard and Dr. Alfonso Ortega, Jr., respectively, for logistic assistance. K. Buis, AB Seed Laboratory, Norcross, GA, provided valuable assistance. We are grateful to T. Fulbright, E. Grahmann and T. Falk for reviewing this paper and improving it with their constructive criticism. Financial assistance from numerous supporters of the Caesar Kleberg Wildlife Research Institute including the Brown Foundation made this research possible. This is Caesar Kleberg Wildlife Research Institute manuscript number 16-109, Texas A\&M University-Kingsville, TX and publication number 002 of the East Foundation.

\section{References}

Baldos, O.C., J. DeFrank, M. Kramer and G.S. Sakamoto. 2014. Storage humidity and temperature affect dormancy loss and viability of tanglehead (Heteropogon contortus) seeds. HortScience 49:1328-1334.

Bielfelt, B.J. 2013. Invasion by a native grass: Implications of increased dominance of Heteropogon contortus (tanglehead) for grassland birds. MS thesis, Texas A\&M University-Kingsville.

Boyd, N.S. and R.C. Van Acker. 2003. The effects of depth and fluctuating soil moisture on the emergence of eight annual and six perennial plant species. Weed Science 51:725-730.

Brown, J.H., O.J. Reichman and D.W. Davidson. 1979. Granivory in desert ecosystems. Annual Review of Ecology and Systematics 10:201-227.

Carino, D.A. and C.C. Daehler. 1999. Genetic variation in an apomictic grass, Heteropogon contortus, in the Hawaiian Islands. Molecular Ecology 8:2127-2132.

Carter, M.G. 1958. Reclaiming Texas brushland range. Journal of Range Management 11:1-5.

Clements, D.R., D.L. Benott, S.D. Murphy and C.J. Swanton. 1996. Tillage effects on weed seed return and seedbank composition. Weed Science 44:314-322.

El-Maarour-Bouteau, H., C. Mazuy, F. Corgineau and C. Bailly. 2011. DNA alteration and programmed cell death during ageing of sunflower seed. Journal of Experimental Botany 62:5003-5011.

Emery, W.H.P. and V.W. Brown. 1958. Apomixis in the Gramineae. Tribe Andropogoneae: Heteropogon contortus. Madrono 14: 238-246.

Everitt, J., D.L. Drawe, C.R. Little and R.I. Lonard. 2011. Grasses of South Texas: A Guide to their Identification and Values. Lubbock, TX: Texas Tech University Press. 
Gould, F.W. 1968. Grass Systematics. New York, NY: McGraw-Hill Book Co.

Gould, F.W. 1978. Common Texas Grasses, an Illustrated Guide. College Station, TX: Texas A\&M University Press.

Grace, J.L., D.B. Wester, F. Bryant, J. Edwards and F. Hernandez. 2015. Tanglehead research in south Texas rangelands. Caesar Kleberg Wildlife Research Institute, Newsletter, August, 2015. Caesar Kleberg Wildlife Research Institute, Texas A\&M University-Kingsville, www.ckwri.tamuk.edu/home/news/article/ tanglehead-research-on-south-texas-rangelands/

Grundy, A.C., A. Mead and S. Burston. 2003. Modelling the emergence response of weed seeds to burial depth: Interactions with seed density, weight and shape. Journal of Applied Ecology 40:757-770.

Gulden, R.H. and S.J. Shirtliffe. 2009. Weed seed banks: Biology and management. Prairie Soils and Crops Journal 2:46-52.

Honda, Y. 2008. Ecological correlations between the persistence of the soil seed bank and several plant traits, including dormancy. Plant Ecology 196:301-309.

Leck, M.A., V.T. Parker and R.L. Simpson (eds). 2008. Seedling Ecology and Evolution. Cambridge, UK: Cambridge University Press.

Leishman, M.R., G.J. Masters, I.P, Clarke and V.K. Brown. 2000. Seed bank dynamics: The role of fungal pathogens and climate change. Functional Ecology 14:293-299.

Meyers, R.H., D.C Montgomery and G.G. Vining. 2002. Generalized Linear Models with Applications in Engineering and the Sciences. New York, NY: John Wiley and Sons.

Pathak, P.S. and S.S. Parihar. 2004. Seed production and germination studies of spear grass in dry grasslands of central India. Bulletin of the National Institute Ecology 14:33-41.

Peart, M.H. 1979. Experiments on the biological significance of the morphology of seed-dispersal units in grasses. Journal of Ecology 67:843-863.

Powell, A.M. 1994. Grasses of the Trans-Pecos and Adjacent Areas. Austin, TX: University of Texas Press.

Roberts, H.A. 1962. Studies on the weeds of vegetable crops: II. Effect of six years of cropping on the weed seeds in the soil. Journal of Ecology 50:803-813.

Steel, R.G.D, J.H. Torrie and D. Dickey. 1997. Principles and Practices of Statistics: A Biometrical Approach, 3rd ed. New York, NY: McGraw-Hill, Inc.

Stubbendieck, J., S.L. Hatch and L.M. Landholt. 2003. North American Wildland Plants, a Field Guide. Lincoln, NE: Univ. Nebraska Press, Lincoln.

Tothill, J.C. 1970. Reproductive behavior as it affects the distribution and patterns of response of Heteropogon contortus in tropical and subtropical regions. Pages 30-32 in Proceedings of the Eleventh International Grassland Congress. University of Queensland, St. Lucia.

Tothill, J.C. 1977. Seed germination studies with Heteropogon contortus. Australian Journal of Ecology 2:477-484.

Van Devender, T.R. 1990. Late Quaternary vegetation and climate of the Sonoran Desert, United States and Mexico. Pages. 134-165 in J.L. Betancourt, T.R.Van Devender and P.S. Martin (eds), Packrat Middens, The Last 40,000 Years of Biotic Change, Tucson, AZ: University of Arizona Press.

Wester, D.B. 1991. A summary of range plant seed germination research. International Center for Arid and Semiarid Land Studies Publ. 91-2, Lubbock, TX: Texas Tech University.

Wester, D.B. 1995. Seed physiology and germination. Pages 168 290 in D.J. Bedunah and R.E. Sosebee (eds), Wildland Plants:
Physiological Ecology and Developmental Morphology, Denver, CO: Society for Range Management.

Zhu, Y., M. Dong and Z. Huang. 2009. Response of seed germination and seedling growth to sand burial of two dominant perennial grasses in $\mathrm{Mu}-\mathrm{Us}$ sandy grassland, semiarid China. Rangeland Ecology and Management 62:337-344.

\section{Use of an Airplane and Simulated Aerial Planting to Evaluate Seed Coating, Seed Pelletization, and Seeding Rate on Smooth Cordgrass Vegetation $\mathbb{C}$}

Herry S. Utomo (corresponding author: Louisiana State University Agricultural Center, Rice Research C, Crowley, Rayne, LA 70578, hutomo@agcenter.lsu.edu), Ida Wenefrida (Louisiana State University Agricultural Center, Rice Research Station, Rayne, LA 70578) and Steve D. Linscombe (Louisiana State University Agricultural Center, Rice Research Station, Rayne, LA 70578).

$\triangle$ erial applications using an airplane (crop duster) have Abeen used routinely in the agricultural industry for planting, delivering fertilizers, and spraying herbicides or pesticides. The speed and ease with minimal ground manpower required are the major advantages of aerial applications. In coastal marshes, both water and land vehicles can be used in planting. The levels of difficulty, however, elevate exponentially for places farther away from the main road or boat landings. By using an airplane, it only takes 16 seconds or less to plant a hectare of land. Aerial applications can be used to carry out various missions, from establishing new vegetation to rejuvenating habitats under stress. Smart aerial applicators and unmanned aerial vehicles are being applied in agriculture to improve precision, early detection of disease, weed pressure, crops under stress, and many other aspects of agriculture (TorresSanchez et al. 2013, Zhang and Kovacs 2012, de Castro et al. 2012, Gray et al. 2008). These new tools combined with the large scale aerial planting can be used to develop a comprehensive system to support the overall efforts in controlling coastal erosion and maintaining the health and productivity of coastal ecosystems.

Coastal marsh land loss occurs in many parts of the world. Some occur slower than others. The coastal land loss in Louisiana is among the fastest at the approximate rate of 16.57 square miles per year or the size of a football field every hour (Couvillion et al. 2011). The problem exacerbates with the rise of sea levels. During the last 80 years, the accumulated loss is estimated at approximately

Color version of this article is available through online subscription at: http://er.uwpress.org 